doi:10.7592/FEJF2002.20.yiddish

\title{
LINGUISTIC BIOGRAPHIES OF YIDDISH SPEAKERS IN ESTONIA
}

\section{Anna Verschik}

\section{INTRODUCTION}

Let us imagine a monolingual person, a member of a linguistic majority. If we wish to describe his/her sociolinguistic history, there would hardly be any complications. We can ask what his/her mother tongue is and receive a clear answer.

However, in the case of a multilingual the situation is much more complicated. We will argue below that the question concerning a multilingual's mother tongue cannot be answered in a clear-cut manner. First, multiple definitions of mother tongue are possible and various criteria can be used as a basis. Second, one's identification can alter over a period of time and at different points a person can have different mother tongues.

A sociolinguistic study of a Jewish community always involves a study of multilingualism (Fishman 1991a: 308). There is more to it than that: Yiddish still remains an internally conflicted language and people sharing an ethnocultural identity would often disagree on matters concerning Yiddish (Kerler 1998). Fishman (1991a: 4152 ) has analyzed an example of such a disagreement in his paper on M. Lefin-Satanover, T. Feder and Y. Sh. Bik.

The Baltic states in their first period of independence (1918-1940) serve as a perfect illustration of diversity among Jews. The situation of Yiddish speakers (hereafter YS) in the three countries differed qualitatively and quantitatively (see Verschik, forthcoming), nevertheless, all Baltic states had cultural and educational autonomy for minorities, thus providing conditions for preservation of Jewish national identity through the means of Yiddish or Hebrew. In Estonia, cultural autonomy even encouraged a kind of national revival among urbanized and secularized Jews (Mendelsohn 1983: 254). Yet, as it will become clear from the examples below, language choice

http://www.folklore.eelfolklore/vol20/yiddish.pdf 
Linguistic Biographies of Yiddish Speaker in Estonia

and language use motivation among YSs in Estonia was and continues to be anything but straightforward.

In the present paper we are going to discuss the following matters: the concept of linguistic biography, the reasons why a traditional notion of mother tongue does not work in the case of multilingual individuals and the inadequacy of census statistics. We will give a portrait of an average YS in Estonia and, finally, we will present samples of linguistic biographies.

\section{THE CONCEPT OF LINGUISTIC BIOGRAPHY}

In a situation where multiple language choice is possible we need a description reflecting the whole complexity of the dynamics of linguistic behavior. Multilingualism can be both a societal and an individual phenomenon. Census statistics usually, but not necessarily, show general patterns on societal level. However, in my view, we need some kind of description of individual multilingualism, especially in the case of such a small community as Jews in Estonia (3, 434 or $0.4 \%$ in 1934 and 2,275 or $0.16 \%$ in 2000 ).

For scholars of today, oral history is hardly a new concept. There exist at least two approaches: The 'traditional' history and oral history collected from individuals. Estonian Literary Museum has recently started a project called Estonian biographies (Eesti elulood): anyone was welcome to write down his/her biography and to send it to the Museum. In the same way, we can use a variety of instruments for sociolinguistical analysis: macrosociolinguistics for societal multilingualism and linguistic biographies for individual multilingualism.

During my research on Estonian Yiddish (1995-1999) I conducted interviews with 28 informants. The interviews consisted of three parts. The first part was a structured questionnaire concerning biographical data and language choice matters: what language spoken when, with whom, and where; self-estimation of skills in each language in four domains (reading, writing, understanding, and speaking) etc. The second part was a non-structured recorded interview where respondents were asked to speak about their childhood and youth. In the third part the informants were asked to choose be- 


\section{Anna Verschik}

tween several lexical items. In the course of the first and the second part of the interviews I realized that the biographies of YSs are, in fact, inseparable from their linguistic histories. Circumstances in their lives quite often demanded a chois between several languages, which, nevertheless, did not mean a complete language shift.

Thus, linguistic biography is an empirical term designating the dynamics of language choice, linguistic preferences and competence in a multilingual individual. Further on we will show in what sense the traditional concept of mother tongue is often non-applicable to YSs in general and in our case in particular.

\section{MOTHER TONGUE: CONTRADICTING DEFINITIONS}

Several studies by Skutnabb-Kangas $(1984,2000)$ emphasize the ambiguity of mother tongue concept in the case of multilingual individuals. The answer depends on criteria of mother tongue definition. Skutnabb-Kangas (1984: 18) suggests four criteria: origin, identification (internal and external), competence and function. We shall see how different criteria produce different answers in our case.

\subsection{Origin}

Mother tongue by origin is the language one learned first (the language in which one has established the first long-lasting verbal contact). According to this criterion, most YSs in Estonia can claim Yiddish as their mother tongue. However, very few speakers if any acquired only one language as their first one. Frequently another language was spoken at home in addition to Yiddish (German, Russian, Estonian), or a child had a nurse who would speak a language other than Yiddish (Estonian in most cases), or parents would speak different languages to their children. Most of my informants have a native command of Estonian since their early years and do not remember the process of its acquisition: mir hobn alemol geret estniš 'we have been always speaking Estonian'. 
Linguistic Biographies of Yiddish Speaker in Estonia

\subsection{Identification}

Identification is subdivided into internal (the language one identifies with/as a native speaker of) and external (the language one is identified with/as a native speaker of, by others). Self-identification does not necessarily reflect competence in a given language. There are people with passive knowledge of Yiddish who, nevertheless, symbolically identify themselves with Yiddish: Yiddish = 'our language', 'language of our Jews' (see Fishman 1991b: 22-24 on symbolical relation between a language and a culture). Finally, many speakers have multiple linguistic identities and identify themselves with more than one language.

External identification can contradict internal identification and other criteria as well. For Estonian Jews multilingualism is a rule: they are at least bilingual. Their competence in languages other than Yiddish is not limited to a working command of these languages, but rather they have a complete mastery of at least one language beside Yiddish. Thus, externally they are often identified as native speakers of Estonian and Russian (in some cases German). In the census of 1934 some 80 Jews, no doubt guided by Zionist ideology, claimed Hebrew (Ivrit) to be their 'usual language' (Teine rahvaloendus 1935: 106-107, table 8). However, an Ivrit speech community hardly existed in Estonia. One aspect of Hebrew-Yiddish controversy can be precisely described as a discrepancy between the internal identification of some Jews as native Ivrit speakers and the external identification (based on other criteria) denying this possibility.

\subsection{Competence}

According to competence criteria, the mother tongue is the language one knows best. Competence and internal identification can contradict each other (limited, if any, knowledge of language, but clear self-identification with Yiddish). The picture is even more complex if we try to analyze what competence means.

First, bilingualism does not mean equilingualism (equal competence in each language) and it would be wrong to compare a bilingual to two monolinguals since there are few bilinguals who can pass as an ideal monolingual in each language (Romaine 2000: 6). Grosjean 


\section{Anna Verschik}

(1982: 232) speaks about 'more realistic definitions'. It is reasonable to view fluency as a continuum, whereas a speaker of one language can produce 'complete, meaningful utterance in the other language' (Haugen 1956: 6, 7).

Second, Yiddish is an in-group language and is used in certain domains. Outside of these domains other languages are used. That means that competence in each language is inevitably different because a society does not need two languages for identical functions (Fishman 1977: 1-49, quoted from Clyne 2000: 307-308).

Third, competence can differ in understanding, speaking, reading and writing. Although school instruction in Yiddish was available in Estonia before 1940, clearly not all Yiddish-speaking children attended a Yiddish school. Today, very few are able to read and to write (for details see Verschik 1999).

\subsection{Function}

According to a definition of the mother tongue based on function, the mother tongue is the language one uses most. Today nobody uses Yiddish most, because the domains of its use have decreased after the Holocaust and the Soviet occupation. Use of Yiddish is confined to rather limited number of situations. But even referring to the situation preceding 1940 it is hard to tell what language Jews used most frequently. In brief, the situation can be described by paraphrasing the title of Merrill Swain's Ph.D. thesis: multilingualism is their first language (Swain 1972, paraphrase suggested by Skutnabb-Kangas 2000: 111).

In the case of Yiddish there are factors that make the situation even more complex. As it was stressed by Fishman (1991: 53-54), Yiddish has still remained an internally conflicted language, and people arguing about its symbolic status share 'a common ethnoreligious identity and yet differ as to the language(s) which symbolize(s) that identity for them'. Today it is not altogether clear what 'the Jewish people' means and one should rather speak of subethnic groups in the manner one speaks or Hispanic or Arabic peoples (Fishman 2000: 6-7). I have described the main characteristics of Jewish identity in Estonia elsewhere (Verschik 2000) and will briefly discuss this topic below. 
Linguistic Biographies of Yiddish Speaker in Estonia

\section{CENSUS, IDEOLOGY AND SELF-PERCEPTION}

As it was mentioned in the introduction, census statistics can be problematic in several ways. Some problems are expressed in Fishman (1991b: 40-41). First, census questionnaires contain too few questions concerning languages. Second, a census serves the goals of a 'given sociocultural and ethnolinguistic establishment'. For instance, in Israeli censuses the method of estimation is the 'spoken language'. This means that speakers of some languages who do not regularly use the language they identify themselves with are not counted as speakers of that language. It is not clear how often a language has to be spoken in order to count as 'usually spoken language' (Fishman 1991b: 314, 1999: 22).

In addition to this, a census may sometimes reflect wishful thinking of respondents. We mentioned already the 80 respondents in the Estonian census of 1934 who claimed Hebrew (Ivirt) to be their 'usual language'. A non-specialist can be lead astray by this figure. No doubt it carries important information, but one should ask what this figure really reflects: the existence of a small speech community or self-identification and ideological trends? In the same vein, as a response to Soviet Russification policy many Estonians, Latvians and Lithuanians denied any knowledge Russian and so the number of Balts who know Russian seems suspiciously low in the censuses of 1979 and 1989 (Druviete 2000: 23).

The most significant flaw of many censuses is that they do not allow multiple identity. For instance, the questionnaire related to languages in the recent Estonian census of 2000 allowed only one mother tongue. Languages other than mother tongue were placed under the heading 'other languages that you know: Estonian, Russian, English, German, French, Finnish, Swedish, Latvian, your national tongue, other languages, do not know other languages' (see homepage of Statistical Office of Estonia: www.stat.ee/ loendused). Needless to say that in the case of Jews it is not clear what the national tongue is. Also, language competence was not defined.

Let us return to the opinion of Fishman (2000: 6-7) according to which it would be reasonable to consider various subethnic groups of Jews rather than 'the Jewish people'. Whether we wish it or not, 


\section{Anna Verschik}

there are significant sociocultural and linguistic differences between various groups of Jews in various countries. Such a difference exists between the so-called indigenous and non-indigenous minorities in the Baltic states.

Those who were born before the Soviet occupation, as well as their descendants, are considered as a group indigenous in any given Baltic state. Newcomers from after 1940 are considered as nonindigenous. Indigenous Jews of Estonia have double identity (Estonian/Baltic Jews) and are characterized, among other things, by a native or native-like competence in co-territorial Estonian and selfidentification with pre-1940 Jewish minority and Yiddish. So-called newcomers are mostly Russian monolinguals who do not identify themselves with Yiddish, have loose ties with Estonia and its culture (see details in Verschik 2000). In his article on Jews of Latvia and Estonia, Kupovetski (1986) emphasizes the difference between indigenous and non-indigenous groups and notes that often indigenous Jews have culturally and linguistically more in common with the co-territorial majority than with non-indigenous Jews. Unfortunately, this difference is not reflected in censuses.

This leads us to the next section where we will try to give a portrait of a YS in Estonia.

\section{A PORTRAIT OF A YIDDISH SPEAKER IN ESTONIA}

The following portrait is based on my personal communication with YSs and on facts of their (linguistic) biographies.

\subsection{General background}

A YS is not younger than 60 , lives in Tallinn (the capital) or in Tartu (the university town) and quite often has a non-Jewish (Estonian) spouse. Traditional Jewish learning and Hebrew (lošn-kojdeš) has played practically no role in Estonia: the parents of today's YSs were already rather secularized.

A YS has a native(like) command of at least two languages. In addition to Estonian and Russian, a YS speaks the local Yiddish dialect (Estonian Yiddish) and has practically no contacts with Standard 
Linguistic Biographies of Yiddish Speaker in Estonia

Yiddish. There are several reasons for this. The Jewish minority has always been practically invisible and steadily constituted $0.4 \%$ of the whole population before 1940 . Today the figure is $0.16 \%$. Despite rather lively activities in the range of cultural autonomy there was hardly any local Yiddish press and, in contrast to Latvia and Lithuania with their broad network of various Jewish schools, there were only three Jewish schools of which two had Yiddish as a language of instruction. All Jews had competency in language(s) other than Yiddish and often attended a non-Jewish school and thus had contact with spoken Yiddish only. Estonian Yiddish is a rather homogenous dialect and there is little if any regional variation. As a rule, speakers have no contact with other Yiddish dialects (Verschik 1999).

Needless to say that during the Soviet rule there were no Jewish schools and the only kind of Yiddish available were Soviet publications in Soviet Yiddish spelling. For those who had at least some educational background in Yiddish these publications were unacceptable for symbolic, ideological and practical reasons. For instance, Liia K. from Tallinn (born in 1922) told me that it required from her a great effort to read Yiddish books printed according to Soviet Yiddish standard and she ceased reading in Yiddish altogether.

\subsection{Yiddish literacy}

The above-mentioned circumstances have lead to a dramatic decrease in Yiddish literacy. A YS would thus lack writing competence and, at best, would be able to read but not to write Yiddish. There are instances when oral communication is in Yiddish and written communication in another language.

When asked to estimate one's competence in understanding, speaking, reading, and writing, some respondents stated that they do not know whether they are able to read Yiddish anymore because they had not done it for $40-50$ years. They usually read press and fiction in other languages.

\subsection{Education}

Very few had the same language of instruction during their school years. The number of students attending Jewish or Estonian schools 


\section{Anna Verschik}

was increasing at the expense of Russian and German schools. Yet in some localities (Pärnu, Rakvere) German orientation was still strong. Change of schools and language of instruction was quite usual. The struggle between Yiddishists and Hebraists affected choice of school: Hebraists prevailed in the so-called cultural self-government and it happened only after considerable pressure from Yiddish-speaking parents that Yiddish was introduced as a language of instruction in the Tallinn Jewish Gymnasium alongside Hebrew (Ivrit). If a Jewish school did not offer the language parents wished (i. e., Ivrit instead of Yiddish), the parents sent their children to a non-Jewish school.

It has to be mentioned that Ivrit was nobody's first language. Children had to study in a completely foreign language. Graduates (except those who later emigrated to Palestine/Israel) have never used it actively. As a rule, they have almost forgotten the language.

Estonian is usually the language of higher or professional education.

\subsection{Language attitudes}

The speakers perceive Yiddish as 'our' language, even if one has a better competence in a language other than Yiddish. Practically all of them think that the dialect they speak is actually Standard Yiddish, or the latter is at least based on their dialect. Estonian Yiddish has developed on the basis of Courland Yiddish and together with the various dialects of Lithuania and Belarus belongs to the North Eastern group of Yiddish dialects. Nevertheless the speakers apprehend certain historical sociocultural differences between Lithuania on the one hand and Courland and Estonia on the other (for a detailed description see Mendelsohn 1983). That is the reason why they think of themselves as 'Baltic Jews' and not 'Lithuanian Jews': mir zajnen nit kejn litvakes, mir zajnen baltiše 'we are not Litvaks, we are the Baltic ones'.

A YS is a speaker of other languages and belongs to different speech communities at the same time. Constant codeswitching is a usual strategy for in-group communication, so that several persons have told me that it would be extremely difficult to tell what language they speak to other YSs. 
Linguistic Biographies of Yiddish Speaker in Estonia

\section{CONCLUSIONS}

We have seen that in the case of multilingual individuals it is extremely hard to describe adequately their linguistic history using the traditional instruments of census or the concept of mother tongue. In addition to the usual difficulties related to the description of multilingualism there are difficulties related to the complexities in the situation of Jewish languages in particular, i.e. it is not clear what the national language of Jews is.

Applying to multilinguals different definitions of mother tongue (based on origin, internal/external identification, competence and function) we obtain different results: a YS seldom has one mother tongue even according to origin criterion, and identification would often contradict competence. If we consider function (language used most frequently), then Yiddish is nobody's mother tongue, which contradicts competence and identification. Censuses seldom allow for double identity, however, it is crucial for self-identification of the indigenous Jewish minority.

Linguistic biographies could hopefully help where other tools fail. Linguistic biographies do not permit making far-fetching conclusions on a sociolingusitic situation in general, yet they do shed light on details that otherwise remain invisible. A comparative study of linguistic biographies of YSs in the Baltic countries could be an interesting topic for future research.

\section{SAMPLES OF LINGUISTIC BIOGRAPHIES}

Two linguistic biographies are given in this section. In each biography I try to highlight the following matters: first language(s) learned, self-identification, language choice and attitude.

Eugenia G.-L. (1922-2001) was born in Rumania. However, this does not automatically mean that her parents and herself were speakers of Rumanian Yiddish. Eugenia's father was temporarily working in Rumania. Her parents spoke a variety of North Eastern Yiddish and other languages as well. This is a rare case when both parents of a YS from Estonia were born outside Estonia. Eugenia would speak Russian to her farther and German to her mother. 


\section{Anna Verschik}

The father, Mr. G., was invited to work as a principal of the Jewish Gymnasium in Tallinn, so in 1925 the family moved to Estonia. The mother with her love for the German language felt quite comfortable in the country that had had a history of German cultural dominance. Both parents quickly learned Estonian and became Estonian citizens. Estonian culture did not remain strange to them. Eugenia stated that her parents used to go to performances in Estonian theaters and occasionally read Estonian books.

Mr. G. was a historian, a graduate of the University of Warsaw. He had a profound knowledge of Jewish history and, being the principal of the Jewish Gymnasium, was the right person in the right place. However, he was upset by the internal struggle between adherents of Yiddish and Hebrew and tried to do his best to avoid bringing politics into school life.

Eugenia heard Yiddish from family friends, had a good command of Russian and Estonian but identified herself with the German language and culture. She spoke German with her mother and with most of her friends. She wanted to be sent to a German school. Her father as the principal of the Jewish school, however, could not allow this because that would have damaged his professional reputation. Eugenia got instruction in Hebrew (Ivrit), but she did not like the language and was very upset by her parents' choice. She had no interest in Zionism and thought that she did not need Hebrew. During recess she spoke German and sometimes Yiddish (the variety spoken in Estonia). I asked her whether she remembers Hebrew to be spoken at school during recess and the answer was negative. Other graduates reported the same.

Eugenia graduated from school in 1940 . She wanted to become a historian and enrolled in the philosophy department of the University of Tartu. But due to the events of 1940-1941 she had practically no chance to study there. In 1941 the family was evacuated to Russia. In 1944 she returned to Estonia. She discovered that her Estonian had deteriorated during her stay in Russia, but she quickly regained her competence. It was clear that under the Soviet rule she could not overtly show her pro-German cultural orientation. Eugenia graduated from the Polytechnical Institute and later she became an instructor in economics. She lectured both in Russian and Estonian. She spoke both languages grammatically correctly 
Linguistic Biographies of Yiddish Speaker in Estonia

but with a German accent. This accent, however, was not audible in her Yiddish, since Baltic German (the variety spoken in the Baltic countries) and Estonian Yiddish have a similar articulatory basis.

She had completely forgotten Hebrew. With her Jewish friends she would speak German, Yiddish, Russian and Estonian or a mixture of these languages. In the late 1980s the national awakening of Estonians was accompanied by general rise of national self-consciousness of other minorities. In 1988 the Jewish Cultural Society was organized, and Eugenia became one of its activists and a kind of amateur historian. She discovered that she had not forgotten Jewish characters and was able to read in Yiddish but not in Hebrew. Eugenia considered Yiddish as an important part of cultural identity and never showed anti-Yiddish attitudes of any kind.

After Estonia restored the independence in 1991 she established connections with the German embassy and subscribed to Germanlanguage periodicals. Needless to say that she had mixed feelings towards Germany but preserved her affection towards the language and culture. I had a chance to attend a conference in Germany in 1995 together with her. The conference was dedicated to Jewish history in Latvia and Estonia and many descendents of Baltic Germans were present. They could not help admiring Eugenia's Baltic German, a variety that has almost become extinct.

This is a complicated biography reflecting a multiple cultural and linguistic identity. Probably the label Baltic-Jewish would be the most appropriate.

Ita L. was born in 1927 in the town of Võru and spent her childhood in Tartu. During the interview she claimed that the family language was German but probably it was both Yiddish and German that her parents spoke. She stated that both her parents spoke perfect Estonian. As for herself, she acquired the language in her early childhood from her nanny and neighborhood children. Later she had a German governess.

Ita entered an Estonian-language school. Whenever her classmates had difficulties with Estonian grammar they would ask for her help. The foreign language was of course German. Thus, in her child- 


\section{Anna Verschik}

hood she was fluent in three languages and literate in two. She never learned how to write or read Yiddish.

During the war the family was evacuated to Tshuvashia. Ita who used to know 'all languages' was now suddenly without a language: Yiddish, Estonian and German were of no use there. She had to continue her education. There was only a Tshuvashian school in the locality where the family lived. It did not take long to pick up basic Tshuvashian. Ita stated she had acquired the language via communication and never learned the grammar systematically. According to her estimation, her knowledge was not perfect, but it was sufficient for school.

Having graduated from this seven-year school she wanted to complete her secondary education. That meant attending a secondary school far away and mastering Russian that she had not previously known. She stated that it was not too complicated a task. After the war the family returned to Estonia. Ita still had to attend a secondary school for another year. Now she felt more proficient in Russian than in Estonian (German-language schools were no longer there). So she graduated from a Russian school but decided to continue her education in Estonia.

Ita wanted to study medicine at the University of Tartu. She had to pass entrance the examinations in physics, chemistry, and a foreign language, and to write an essay. She did not worry about her foreign language exam (German) and about the essay. She felt that her Estonian was sufficient for it. However, physics and chemistry seemed to pose a problem because after a Russian-language school she did not know appropriate terms in Estonian. So she asked the examiners whether she could answer in Russian. The permit was granted and she passed her examinations successfully.

Ita's husband was a physician, too. She could not tell me what language exactly they spoke: sometimes it was Yiddish and sometimes Estonian. She claims that Estonian is the language she knows best, but her Yiddish speech is fluent and enjoyable. She continued speaking Yiddish to her parents. Her children understand Yiddish but do not speak it fluently. Both children have studied medicine at the University of Tartu. Ita stated that at a certain point her son was 
Linguistic Biographies of Yiddish Speaker in Estonia

her colleague at a hospital and they would speak Yiddish as a secret language there.

She has almost forgotten Tshuvashian except for folksongs and some elementary phrases. She claims that she never code-switches, nevertheless I have frequently observed her doing this. Alternate use of various languages is so common in her life that sometimes it is hard to recall in what language a certain event took place. I asked Ita whether she had attended a kindergarten and in what language. She answered positively but could not recall the language of instruction. Then she started thinking aloud about the children in the kindergarten. She recalled their names: there was Kurtchen and Lieschen, so it had to be a German kindergarten.

Several years ago Ita joined her daughter's family in the USA. I have no information concerning the state of her English, but, taking into account the facts of her linguistic biography, I am sure she has acquired it at least at a basic level.

\section{References}

Clyne, Michael 2000. Multilingualism. Columas, Florian (ed.) The Handbook of Sociolinguistics. Oxford: Blackwell, pp. 301-314.

Druviete, Ina 2000. Sociolinguistic situation and language policy in the Baltic states. Riga: Universtity of Latvia, Baltic Studies Programme.

Fishman, Joshua A. 1977. The social science perspective: keynote. Fishman, Joshua A. (ed.). Bilingual Education: Current Perspectives. Washington, DC: Georgetown University, pp. 1-49.

Fishman, Joshua A. 1991a. Yiddish: Turning to Life. Amsterdam \& Philadelphia: John Benjamins Publishing Company.

Fishman, Joshua A 1991b. Reversing Language Shift. Clevedon \& Philadelphia \& Adelaide: Multilingual Matters.

Fishman, Joshua A. 1999. Vifl yidn redn yidish? Afn Shvel 316 (OctoberDecember), 22.

Fishman, Joshua A. 2000. Tsi veln mir blaybn bay di zelbe alte gedanken. Afn Shvel 317 (January-March), pp. 6-8.

Fishman, Joshua A. 2001. Shprakh-planirung far di "andere ydishe leshoynes". Afn Shvel 321 (January-March), pp. 8-11.

Grosjean, François 1982. Life with Two Languages. Cambridge, Massachusetts \& London, England: Harvard University Press.

Haugen, Einar 1956. Bilingualism in the Americas: a bibliography and research guide. Alabama: University of Alabama Press. 


\section{Anna Verschik}

Kerler, Dov-Ber 1998. On the "Politics of Yiddish". Kerler, Dov-Ber (ed.). The Politics of Yiddish. Walnut Creek \& London \& New Delhi: AltaMira Press, pp. 1-8.

Kupovetski, Mark 1986. Eynike ongabn vegn yidn in Letland un Estland. Sovetish Heymland 7, pp. 127-130.

Mendelsohn, Ezra 1983. Jews in Central Eastern Europe between World Wars. Bloomington: Indiana University Press.

Romaine, Suzanne 2000. Bilingualism. Oxford: Blackwell.

Skutnabb-Kangas, Tove 1984. Bilingualism or Not? Clevedon: Multilingual Matters.

Skutnabb-Kangas, Tove 2000. Linguistic Genocide in Education - or Worldwide Diversity and Human Rights? Mahwah, New Jersey: Lawrence Erlbaum Associates.

Swain, Merrill 1972. Bilingualism as the first language. Ph.D. dissertation. California, University of Irvine.

Verschik, Anna 1999. Some aspects of multilingualism of Estonian Jews. International Journal of the Sociology of Language 139, pp. 49-67.

Verschik, Anna 2000. Estonian Jews: Integration and Language Choice. Vebers, Elmars (ed.). Integracija un etnopolitika. Riga: University of Latvia, Institute of Philosophy and Sociology, pp. 215-229.

Verschik, Anna (forthcoming) Yiddish in the Baltic States: Towards Contrastive Sociolinguistics. Lainio, Jarmo \& Kangere, Baiba (eds.). Sociolinguistic Approaches to the Study of Bilingualism in the Northern Baltic Area. Stockholm: Centre for Research on Bilingualism, Stockholm University. 